\title{
Interregional and inter-municipal governance in the Russian Federation: strategic and spatial development trends within the constitutional framework
}

\author{
Ivan Antipin*, Oleg Kozhevnikov, and Olga Ivanova \\ Ural State University of Economics, 620144, 8 Marta Str., 62, Ekaterinburg, Russia
}

\begin{abstract}
The article is devoted to the study of the processes of interregional and intermunicipal governance in the context of the constitutional reform of the public power system in the Russian Federation. Trends of strategic and territorial development have been formulated, one of which is the need to develop uniform normatively and economically justified rules for strategizing for regions of various hierarchical levels, including the macroregions and urban agglomerations. The methodological basis of the study is based on the theoretical provisions of the strategic management, regional and spatial economics. This study of interregional and intermunicipal governance in the Russian Federation is based on a comprehensive analysis of existing strategic planning documents, as well as legislative acts by using a combination of methods: logical, dialectical, and causal. The article can be useful to scientists and researchers, experts, including state and municipal employees involved in the formation (development and updating), as well as the implementation and control over the implementation of the strategies for the socio-economic development of the territories and other interested persons.
\end{abstract}

\section{Introduction}

Interregional and intermunicipal cooperation has long been of interest in the study of management processes in many countries. It is believed that the development of interregional and intermunicipal cooperation increases the efficiency of many state and municipal services, allows more efficient use of available resources [1-3]. It is no coincidence that many countries are creating tools and mechanisms aimed at stimulating the development of interregional and intermunicipal cooperation [4,5].

Of particular interest is still the development of agglomerations, which are considered along with the largest cities as drivers of economic growth in systems of spatial development $[6,7]$.

\footnotetext{
*Corresponding author: aia@mail.ru
} 


\section{Materials and Methods}

On January 20, 2020, Russian President Vladimir Putin submitted a draft law of the Russian Federation to the State Duma on an amendment to the Constitution of the Russian Federation "On improving the regulation of certain issues of organizing public authority." This draft law passed all stages of the federal legislative process and was approved by a national vote. $77.92 \%$ of voters voted for the amendments to the Basic Law, $21.27 \%$ against with a total turnout of $65 \%$.

One of the novelties of the text of the Constitution of the Russian Federation was the emergence of the "public power" legal category, by which, obviously, one should understand the totality of state and municipal authorities and the powers they perform. At the same time, the provisions of Article 12 of the Constitution of the Russian Federation "... local government bodies are not included in the system of state authorities" are preserved. The construction of a unified system of public authority is aimed, first of all, at increasing the effective interaction between state and municipal bodies.

At the same time, in addition to the obvious need to optimize the powers and spheres of responsibility of the levels of state power and local self-government, increased attention is also required to extraterritorial forms of government, for example, the management of the macroregions and agglomerations. In contrast to the "traditional" ones in the system of law of the federal, regional and municipal levels of public administration, the above-mentioned levels of territorial administration are still poorly studied both in scientific and law enforcement terms, therefore, the issues of establishing modern problems of interregional and intermunicipal governance in the Russian Federation require additional attention within the framework of the ongoing constitutional reform of state and municipal administration, in order to determine the most effective, both legal and managerially, trends in strategic and territorial development.

This study of interregional and intermunicipal governance in the Russian Federation is based on a comprehensive analysis of existing strategic planning documents, as well as legislative acts by using a combination of methods: logical, dialectical, and causal.

\section{Results and Discussion}

According to Article 3 of the Federal Law dated June 28, 2014 No. 172-FZ "On Strategic Planning in the Russian Federation", a macroregion is a part of the territory of the Russian Federation, which includes the territories of two or more constituent entities of the Russian Federation, the socio-economic conditions which require the allocation of the specific areas, priorities, goals and objectives of socio-economic development in the formulation of the strategic planning documents.

One of the modern tasks of the socio-economic development of our country is to ensure the effective spatial development. To solve this problem, the "Spatial Development Strategy of the Russian Federation until 2025" was developed, approved by the Order of the Government of the Russian Federation dated 13.02.2019 No. 207-p. One of the goals of the Spatial Development Strategy of the Russian Federation until 2025 (hereinafter referred to as the RF SPS) is to reduce the interregional differences in the level and quality of life of the population [12]. RF SPS is called upon, among other things, to ensure national security, sustainable balanced spatial development of Russia, reduce interregional differences in the level and quality of life of people, and accelerate the rates of economic growth and technological development. According to RF SPS, the territory of the Russian Federation is divided into 12 macroregions - Central, Central Chernozem, North-West, North, South, North-Caucasian, Volgo-Kama, Volga-Ural, Ural-Siberian, South Siberian, Angara- 
Yenisei, Far Eastern. For each macro-region, on the basis of the competitive advantages, promising economic specializations were identified.

It should be noted that the modern macro-regions of the Russian Federation, according to the list of subjects included therein, and, accordingly, along the territorial boundaries, do not coincide either with the existing economic regions or with the federal districts, which significantly complicates their legal regulation and ensuring the unity of the legal space throughout the territory of the Russian Federation. Questions about who will head the macroregions, what tools will be used to manage them, what methods of interaction they will differ from other territorial entities, etc. still remain open in Russian legislation.

Of course, interregional development has certain competitive advantages over the regional development itself or over the processes of the regional competition. Realizing this, the authorities of the constituent entities of the Russian Federation are developing concepts, projects and other documents of interregional (macroregional) development. In particular, in the Sverdlovsk region in 2016, the concept of the project of interregional interaction "Ural Constellation" was developed and presented - system interregional connections, stably and purposefully formed between the centers of regions and urban agglomerations, centers of production, transportation and distribution, through the coordinated implementation of federal, interregional and inter-municipal development projects. However, these projects are isolated and have not yet found their quality regulatory support. It should be noted that the issues of forecasting the effectiveness of socio-economic transformations in regions of various hierarchical levels are currently of interest to the researchers [8].

As noted earlier, the change in the text of the Constitution of the Russian Federation within the framework of building a unified system of public power affected not only the federal and regional level of government, but also did not pass by the lowest level of the democracy - the local government. It should be noted that at this level as well, a number of unexplored and debatable issues of inter-municipal (inter-territorial) governance arise. In particular, many unresolved issues both in legal terms and in terms of implementation mechanisms remain within the framework of such a concept as "agglomeration". This term is quite often found in the works of domestic researchers [for example, 9, 10].

In RF SPS, such concepts as "large urban agglomeration" and "largest urban agglomeration" are used, differing only in the size of the estimated population. According to RF SPS, an agglomeration is a set of compactly located settlements and territories between them with a total population of 500 thousand - 1000 thousand people (for a large urban agglomeration) or more than 1000 thousand people (for the largest urban agglomeration), connected by a joint use of infrastructural facilities and united by intensive economic, including labor, and social relations. These definitions do not reflect the formation features, principles and mechanisms of management and development of agglomerations as objects of spatial organization.

It should also be noted that neither the Federal Law dated 28.06.2014 No. 172-FZ" On Strategic Planning in the Russian Federation", nor the Federal Law dated 06.10.2003 No. 131-FZ "On the General Principles of Organization of Local Self-Government in the Russian Federation" define the agglomeration term. The lack of legally developed definitions and consolidated regulatory acts of integrated approaches to the development of an agglomeration already creates significant difficulties in the implementation of strategic and territorial planning of the territories included in the agglomeration.

In the Russian Federation, over the past decades, agglomerations are considered to a greater extent as the forms of inter-municipal cooperation. Article 8 of the Federal Law dated 06.10.2003 No. 131-FZ "On the General Principles of Organization of Local SelfGovernment in the Russian Federation" says about the council of municipalities, which is created for the purpose of interaction of the local governments in each subject of the 
Russian Federation. On a voluntary basis, other associations of municipalities may be formed, the activities of which are carried out in accordance with the requirements of the Federal Law dated 12.01.1996 No. 7-FZ "On Non-Commercial Organizations". As for the development of the forms of intermunicipal cooperation, Articles 68 and 69 of the Federal Law dated 06.10.2003 No. 131-FZ "On the General Principles of Organization of Local Self-Government in the Russian Federation" mention the inter-municipal organizations that can be created by making the appropriate decisions by the representative bodies of the municipalities.

However, there is still no comprehensive legal regulation of the management of urban agglomerations. This creates a number of problems in the implementation of various types of urban agglomerations. For example, restrictions on the use of property and finance in contractual forms of cooperation on the territory of the agglomeration, the lack of contractual forms of cooperation due to low negotiability, the priority of administrative methods of management and the specifics of the work of control bodies, the impossibility of a radical change in the existing administrative-territorial structure, the lack of legal mechanisms for joining efforts municipalities and the state in the management of urban agglomerations, etc.

The solution to the above issues in the management of agglomeration processes can be the Federal Law "On urban agglomerations", which was developed and presented to the expert community in 2020, pursuant to the Order of the Government of the Russian Federation dated December 27, 2019 No. 3227-p "On approval of the implementation plan for the Spatial Development Strategy of the Russian Federation until 2025". According to Article 3 of the said document, an urban agglomeration is the territory of an urban district or an urban district with an intracity division, or a city of federal significance and adjacent municipalities, where the socio-economic conditions are characterized by intensive economic, including labor ties and joint use infrastructure facilities.

When implementing the normative regulation of agglomeration development, it is important to take into account the basic economic principles of their management, already developed and substantiated in science and practice: integration, but not administrative transformations; priority of contractual models rather than directives "from above"; agglomeration interaction should be based on inter-municipal cooperation and cooperation with the subject of the Russian Federation; institute of joint territorial planning as a mechanism for managing the development of urban agglomeration; expanding opportunities for joint strategic planning, etc.

When improving the regulatory framework for the development of urban agglomerations, one should also take into account the existing practice of various regions of Russia in the formation of common strategic approaches, common patterns, principles, methods, and general patterns for the development of an agglomeration. So, for example, back in 2016, the Deputy Governor of the Sverdlovsk Region, and currently the Head of Yekaterinburg A.G. Vysokinsky voiced the need to develop 6 basic ptterns that are universal for the formation of any agglomeration [11]. We believe that the development of such patterns and their regulatory support can significantly increase the efficiency of the regulatory regulation of agglomeration development processes. 


\section{Conclusion}

In the conclusion of this study, we would like to refer to the practice of the Constitutional Court of the Russian Federation, which has repeatedly pointed out the constitutional foundations of the unity of public authority in the Russian Federation and the objective need for interaction with the local government bodies of the state authorities of the constituent entity of the Russian Federation, designed to create the conditions for ensuring the sustainable and comprehensive social economic development within the entire territory of this constituent entity of the Russian Federation (Resolutions of December 24, 2012 No. 32-П and of December 01, 2015 No. 30-П).

It seems that within the framework of ensuring the unity of approaches to building a system of public power in the Russian Federation, in addition to improving the regulatory framework for the interaction of "traditional" levels of public authority (federal, regional and municipal), it is important not to forget about the need to improve the legal regulation of interregional and intermunicipal governance in the Russian Federation, while it is imperative to take into account the emerging trends of the strategic and territorial development of these levels of management:

Constant complication of the processes of the strategic management of various territories and mechanisms for the implementation of the strategic and territorial planning documents;

When determining the principles, models, instruments of interregional and intermunicipal governance, one should take into account not only the legal aspects, but also issues of economic expediency;

The regulation of interregional and intermunicipal governance, of course, requires the simultaneous systematization of the regulatory support of territorial planning documents;

The need to develop the uniform regulatory and economically sound strategy rules for regions of various hierarchical levels, including macroregions and urban agglomerations, as well as mechanisms for their management.

\section{Acknowledgements}

The article was prepared with the financial support of the RFBR of the research project No. 20-010-00824 "Incremental approach to the formation and implementation of socio-economic development strategies for the Russian Federation regions of different hierarchical levels: uniform rules of strategizing".

\section{References}

1. G. Bel, M. Sebő, Urban Aff. Rev. (2019)

2. A. M. Allers, J.A. De Greef, Local Gov. Stud., 44 (2018)

3. S. Kim, Cities, 104 (2020)

4. G. Citroni, A. Lippi, S. Profeti, Local Gov. Stud, 39 (2013)

5. N. Rees, Eur. Plan. Stud, 5 (1997)

6. C. Fang, D. Yu, LandscUrban Plan, 162 (2017)

7. N. Brenner, Urban Stud., 36 (1999) 
8. Forecasting the effectiveness of socio-economic transformations in territorial systems. Ekaterinburg: Institute of Economics, Ural Branch of the Russian Academy of Sciences (2008)

9. G. Lappo, Russian Expert Review, 4-5 (22)(2007)

10. V.Ya. Lyubovny, Problems of regulating the development of cities and urban agglomerations in the context of the restructuring of the coal industry (foreign and domestic experience) (2015)

11. I.A. Antipin, Scientific works of the Free Economic Society of Russia, 213 (2018)

12. Strategy of the Russian Federation until 2025" was developed, approved by the Order of the Government of the Russian Federation dated 13.02.2019 No. 207-p, http://www.consultant.ru/ 